\title{
Is otolith microchemistry (Sr: Ca and Ba:Ca ratios) useful to identify Mugil curema populations in the southeastern Caribbean Sea?
}

\author{
E. Avigliano ${ }^{*}$, R. Callicó-Fortunato ${ }^{a}, J$. Buitrago $^{b}$ and A. V. Volpedo ${ }^{a}$ \\ ${ }^{a}$ Instituto de Investigaciones en Producción Animal - INPA-CONICET, Universidad de Buenos Aires, Av. Chorroarín, 280, \\ (C1427CWO), Buenos Aires, Argentina \\ ${ }^{b}$ Estación de Investigaciones Marinas de Margarita, Fundación La Salle de Ciencias Naturales, Final Calle Colón, Punta de \\ Piedras, Isla de Margarita, Nueva Esparta, Venezuela \\ *e-mail: estebanavigliano@conicet.gov.ar
}

Received: January 17, 2014 - Accepted: September 12, 2014 - Distributed: November 30, 2015

(With 4 figures)

\begin{abstract}
The aim of the present study was to evaluate the potential use of otolith microchemistry ( $\mathrm{Sr}: \mathrm{Ca}$ and $\mathrm{Ba}: \mathrm{Ca}$ ratios) to identify silver mullet, Mugil curema, populations in Southeastern Caribbean Sea. Fish samples were collected in 7 areas of Nueva Esparta State (Venezuela). The otolith Sr:Ca and Ba:Ca ratios and water Sr:Ca were determined (by ICP-OES and EDTA volumetric method). Otoliths Sr:Ca and Ba:Ca ratios and Sr:Ca partition coefficient of mullets in Cubagua island (south of the State) were significantly different from ratios in La Guardia (north of the State). A discriminant analysis of otolith Sr:Ca and Ba:Ca ratios separated Cubagua Island from La Guardia values. These results suggest the existence of different mullet groups in the Southeastern Caribbean Sea. For this, the simultaneous use of $\mathrm{Sr}: \mathrm{Ca}$ and $\mathrm{Ba}$ :Ca ratios could be a potential tool to identify populations in the study area.
\end{abstract}

Keywords: Mugilidae, fish resource, otolith, microchemistry.

\section{A microquímica do otólito é um indicador do habitat de Mugil curema no sudeste do Mar Caribenho?}

\begin{abstract}
Resumo
O objetivo do presente estudo foi avaliar o potencial uso da microquímica do otólito (razões $\mathrm{Sr}: \mathrm{Ca}$ e $\mathrm{Ba}: \mathrm{Ca}$ ) para identificar distintas populações de tainha, Mugil curema, no sudeste do mar caribenho. Os peixes foram coletados em 7 áreas do estado de Nueva Esparta (Venezuela). As razões Sr:Ca e Ba:Ca do otólito e a razão Sr:Ca da água foram determinadas (pelo ICP-OES e EDTA método volumétrico). As razões de Sr:Ca e Ba:Ca dos otólitos e o coeficiente de partição das tainhas da Ilha Cubagua (sul do estado) foram significativamente diferentes das razões de La Guardia (norte do estado). A análise discriminante das razões de $\mathrm{Sr}: \mathrm{Ca}$ e Ba:Ca dos otólitos separa os valores da Ilha Cubagua e de La Guardia. Estes resultados sugerem a existência de diferentes grupos de Mugil curema no sudeste do mar Caribenho e que o uso simultâneo das razões Sr:Ca e Ba:Ca poderiam ser uma potencial ferramenta para identificar as populações da área de estudo.
\end{abstract}

Palavras-chave: Mugilidae, recurso pesqueiro, otólito, microquímica.

\section{Introduction}

In the last decade, the analysis of otolith chemical composition has been increasingly used to study fish movements and identify fish stocks (Zlokovitz et al., 2003; Kraus and Secor, 2004; Schuchert et al., 2010; Tabouret et al., 2010; Avigliano and Volpedo, 2013). In this regard, the determination of strontium $(\mathrm{Sr})$ and barium $(\mathrm{Ba})$ concentrations has proven to be of major importance (Campana, 1999; McCulloch et al., 2003; Elsdon and Gillanders, 2005; Hamer et al., 2006; Tabouret et al., 2010; Avigliano et al., 2013). Sr concentration in otoliths was reported to vary mainly due to the chemical composition of the water where

fish live (Campana, 1999; Wells et al., 2003; Kraus and Secor, 2004). In species that frequent environments with large variations in salinity, the concentration of $\mathrm{Sr}$ in the otoliths was found to be positively correlated with salinity (e.g. Kraus and Secor, 2004; Sturrock et al., 2012; Avigliano and Volpedo, 2013). This relationship tends to be weak and ambiguous in marine species due to the relatively constant salinity of this environment (Brown and Severin, 2009; Sturrock et al., 2012). On the other hand, Ba concentrations in otoliths were found to be negatively correlated with water salinity (Miller, 2011; Avigliano et al., 2013). For this, the 
simultaneous analysis of the otolith $\mathrm{Sr}: \mathrm{Ca}$ and $\mathrm{Ba}$ :Ca ratios has been applied in previous years to study life history of fish and the differentiation of fish stocks (Tabouret et al., 2010; Ferguson et al., 2011; Avigliano et al., 2013).

The Mugilidae family, with 17 genera and around 72 species (Nelson, 2006; Harrison et al., 2007; González Castro et al., 2008; Heras et al., 2009), is broadly distributed all over the world. It is represented by eight important commercial species in the Caribbean Sea and north of the southwestern Atlantic (Rivera-Reyes, 2009; Mendonça and Bonfante, 2011). In some regions of the southwestern Atlantic, like Brazil, Mugil curema has not only aquiculture importance (Mendes, 1983), but also has become one of the most important fisheries exploitation on the region (Mendonça and Bonfante, 2011). Moreover, for the last two decades, Venezuela has become the country with the largest fish catch in the Caribbean Sea (500.000 tons per year); dropping by $35 \%$ during 1998-2008 but recovering thereafter (FAO, 2005, 2010). Both artisanal and industrial fishing contribute to the Venezuelan capture production, with the former representing $70 \%$ of the total extractive catches (FAO, 2005). Nueva Esparta is the third most important state in terms of capture fisheries production (10.17\%), after Zulia (12.13\%) and Sucre (57.51\%). In Nueva Esparta State there are many local communities undertaking this activity (FAO, 2005), and emergent nutrient-rich waters resulting in high levels of productivity (Muller-Karger et al., 1989).

The silver mullet $M$. curema is the second most abundant fish resource obtained by artisanal extraction, with its capture and culture providing economic support for small local communities (Marin et al., 2003). Ibañez et al. (2012) determined, using a chronological study of the Sr:Ca ratios in otoliths of $M$. curema, that this species remains most of its life in brackish waters of variable salinity and that it spends a short period in marine waters in Mexican coasts. Also, the proportion of $\mathrm{Sr}: \mathrm{Ca}$ in the otolith core indicated that the individuals can spawn both in freshwater and in marine water. These analyses have special relevance to comprehend the life history of $M$. curema. However, many aspects of the population structure, such as number of stocks or populations connectivity, are yet unknown; especially in Southeastern coasts of the Caribbean Sea where this species is actively exploited. In this sense, the aim of the present study was to evaluate the potential use of otolith microchemistry ( $\mathrm{Sr}: \mathrm{Ca}$ and $\mathrm{Ba}$ :Ca ratios) for the identification of Mugil curema populations in Southeastern Caribbean Sea. This could provide a tool for further studies on the use of habitat and connectivity of the populations.

\section{Material and Methods}

\subsection{Study area and sample collection}

Nueva Esparta State is located in the Caribbean Sea, in northeastern Venezuela, and includes the Coche, Cubagua and Margarita islands. The latter is the largest of the three and has two massifs: the Macanao Peninsula in the west and the Paraguachoa Peninsula in the east, separated by a lagoon (La Restinga) (Figure 1). The mullets were collected during July 2011, with gill nets and identified using the taxonomic keys of Harrison (2002) and Harrison et al. (2007). A total of 112 adult fish were collected and their total length ( $\mathrm{TL}$ in $\mathrm{cm}$ ) recorded. The sagittae otoliths were removed from all fish. The right otoliths from individuals of TL between 23 and $35 \mathrm{~cm}$ were selected: 20 from Cubagua Island, 6 from Punta de Piedras lagoon, 21 from El Guamache, 13 from La Isleta, 15 from Manzanillo, 19 from La Guardia and 11 from La Restinga lagoon. Collection of water samples was performed simultaneously with fish sampling.

\subsection{Elemental otolith chemistry}

Otoliths were weighed to the nearest $0.1 \mathrm{mg}$ in an analytical balance and digested with $50 \%$ nitric acid during 24 hours. Otolith $\mathrm{Sr}$ and Ba concentrations were determined using a inductively coupled plasma-atomic emission spectrometry instrument (ICP-OES Perkin Elmer ${ }^{\circledR}$ Optima 2000 DV, Überlingen, Germany) equipped with cross-flow nebulizer and a quartz ICP torch (method EPA 200.7) (EPA, 1994). Solutions were introduced to the spectrometer using a Perkin-Elmer ${ }^{\circledR}$ AS-90 Plus autosampler. The instrument was cleaned at regular intervals with Milli-Q water (Millipore, Saõ Paulo, Brazil) and 10\% nitric acid matrix to prevent sample memory effects. The detection limits of the ICP-OES were 8 and $10 \mu \mathrm{g} / \mathrm{L}$ for $\mathrm{Ba}$ and $\mathrm{Sr}$, respectively. All measurements were performed in triplicate $(\mathrm{RSD}<4 \%)$. External calibration was performed using the atomic spectroscopy standard QCS 21 (Quality Control Standard), Perkin Elmer ${ }^{\circledR}$ Pure (USA). The operating conditions of the ICP-OES instrument are given in Table 1. The concentration of $\mathrm{Ca}$ was determined by

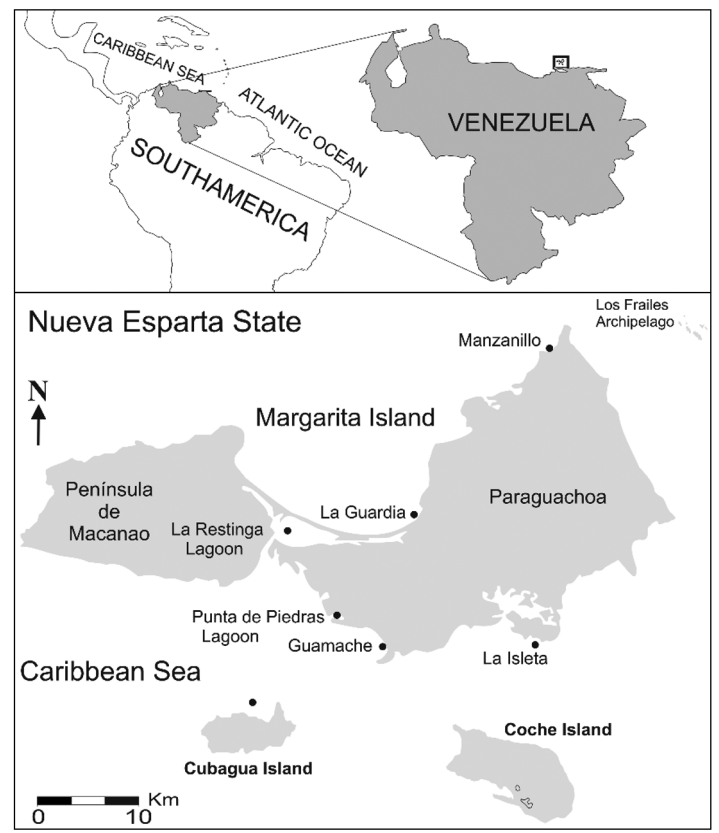

Figure 1. Study area: black spots indicate sampling sites. 
titration with ethylenediaminetetraacetic acid (EDTA) (APHA, 1993). All measurements were made in triplicate (standard deviation less than 4\%). The digestion and analytical procedures were checked by the analysis of Otolith Certified Reference Material for trace elements (FEBS-1, National Research Council, Canada). Replicate analysis of this material showed good accuracy, with the following metal recovery rates: $93 \%$ for $\mathrm{Sr}, 88 \%$ for $\mathrm{Ba}$ and $110 \%$ for $\mathrm{Ca}$. The element:Ca ratios were expressed in mmol mol-1 to standardize the concentrations of trace elements in relation to $\mathrm{Ca}$.

\subsection{Elemental water chemistry}

Water samples were preserved by the addition of $2 \mathrm{~mL}$ of nitric acid per liter of water (APHA, 1993; $3010 \mathrm{~B}$ method), maintained at $4{ }^{\circ} \mathrm{C}$ until further analysis (Chiba et al., 2011). In the laboratory, samples were filtered through a membrane of $0.45 \mu \mathrm{m}$. Water $\mathrm{Sr}$ and $\mathrm{Ca}$ concentrations were determined as described above. Water Ba concentrations were below the detection limit $(8 \mu \mathrm{g} / \mathrm{L})$. Sr:Ca ratios were expressed in $\mathrm{mmol} \mathrm{mol}^{-1}$.

\subsection{Relationships between water chemistry and otolith $\mathrm{Sr}: \mathrm{Ca}$}

In order to examine the relationship between otolith microchemistry and water chemistry, the mean individual elemental ratio ( $\mathrm{Sr}: \mathrm{Ca}$ ) and the averages of all water samples within each site were compared using the partition coefficient described as (Tabouret et al., 2010) (Equation 1):

$D_{S r}=m S r: m C a_{\text {otolith }} / m S r: m C a_{\text {water }}(m=$ molarity $)$

Table 1. Optima 2000 ICP-OES operating conditions for analysis.

\begin{tabular}{lc}
\hline RF Power & $1.3 \mathrm{~kW}$ \\
Plasma gas flow rate & $15.0 \mathrm{~L} / \mathrm{min}$ \\
Nebulizer gas flow rate & $0.80 \mathrm{~L} / \mathrm{min}$ \\
Auxiliary gas flow rate & $0.20 \mathrm{~L} / \mathrm{min}$ \\
Pump flow rate & $1.2 \mathrm{~mL} / \mathrm{min}$ \\
Delay time & $20 \mathrm{seg}$ \\
Flush time & $20 \mathrm{seg}$ \\
Number of replicates & 3 \\
\hline
\end{tabular}

Partition coefficients allow the evaluation of elemental discrimination in the otolith compared to the environment water chemistry (e.g. Kraus and Secor, 2004; Lin et al., 2007; Tabouret et al., 2010; Santos et al., 2013). Sr was estimated for each locality taking into account mean individual $\mathrm{Sr}: \mathrm{Ca}$ values in the otolith and mean $\mathrm{Sr}: \mathrm{Ca}$ ratios in water from the sampling sites where the specimens were caught.

\subsection{Statistical analysis}

ANCOVA was used to determine the effect of fish length on the magnitude of each studied variable. $\mathrm{Sr}: \mathrm{Ca}$ ratios were significantly correlated to fish length and were corrected using the common within-group slope $(b=0.04)$ for fish length variable (Begg et al., 2001; Cardinale et al., 2004; Galley et al., 2006; Burke et al., 2008). This adjustment successfully removed this significant correlation. Subsequently, otolith element:Ca ratios means were compared among sampling sites using one-way analysis of variance (ANOVA), followed by Tukey test (Sokal and Rohlf, 1995). Sr:Ca ratios of water samples were compared among study sites with a Kruskal-Wallis test. Finally, partition coefficients were compared among sampling sites using a one-way analysis of variance (ANOVA), followed by Tukey test.

\section{Results}

\subsection{Elemental otolith chemistry}

The otolith Sr:Ca ratio ranged from 2.65 to $3.64 \mathrm{mmol} / \mathrm{mol}$, with the lowest value corresponding to mullets from $\mathrm{La}$ Guardia and the highest to those collected near Cubagua Island (Table 2). Tukey's test (Table 2) showed three groups: La Guardia, the lagoons (La Restinga and Punta de Piedras) and Cubagua Island. No significant differences were found between Guamache and La Isleta. The mean $\mathrm{Sr}: \mathrm{Ca}$ ratios of the areas previously mentioned were intermediate values between the ones of the lagoons and the ones of $\mathrm{La}$ Guardia. Manzanillo Sr:Ca ratio (3.12 \pm 0.49$)$ was higher than the Lagoons and lower than Cubagua Island (Table 2).

The otolith $\mathrm{Ba}: \mathrm{Ca}$ ratio ranged from 0.009 to $0.024 \mathrm{mmol} / \mathrm{mol}$, with the lowest value corresponding to fish from La Guardia and the highest to fish collected in Cubagua Island (Tabla 2). Tukey's test (Table 2) showed two distinct groups: La Guardia and Cubagua Island. $\mathrm{Ba}: \mathrm{Ca}$ ratios for the remaining areas were intermediate between

Table 2. One-way ANOVA results for the comparison of otolith $\mathrm{Sr}: \mathrm{Ca}$ and $\mathrm{Ba}: \mathrm{Ca}$ ratios $(\mathrm{mmol} / \mathrm{mol})$ of Mugil curema among sampling sites.

\begin{tabular}{|c|c|c|c|c|c|c|c|c|}
\hline \multirow[b]{2}{*}{ La Guardia } & \multirow{2}{*}{$\frac{\mathbf{N}}{22}$} & \multicolumn{4}{|c|}{ Sr:Ca ratio } & \multicolumn{3}{|c|}{ Ba:Ca ratio } \\
\hline & & $2.65 \pm 0.38$ & $\mathrm{~A}$ & & & $0.009 \pm 0.003$ & $\mathrm{~A}$ & \\
\hline Guamache & 21 & $2.97 \pm 0.33$ & $\mathrm{~A}$ & $\mathrm{~B}$ & & $0.013 \pm 0.007$ & A & B \\
\hline La Isleta & 15 & $2.86 \pm 0.74$ & $\mathrm{~A}$ & B & & $0.023 \pm 0.013$ & A & B \\
\hline La Restinga Lagoon & 11 & $3.10 \pm 0.29$ & & B & & $0.013 \pm 0.007$ & A & B \\
\hline Punta de Piedras Lagoon & 6 & $3.12 \pm 0.17$ & & $\mathrm{~B}$ & & $0.013 \pm 0.005$ & A & B \\
\hline Manzanillo & 16 & $3.12 \pm 0.36$ & & $\mathrm{~B}$ & $\mathrm{C}$ & $0.016 \pm 0.008$ & A & B \\
\hline Cubagua Island & 22 & $3.64 \pm 0.49$ & & & $\mathrm{C}$ & $0.024 \pm 0.010$ & & $\mathrm{~B}$ \\
\hline
\end{tabular}

Significant differences are shown with different letters $(\mathrm{p}<0.05)$. N: Sample size. 
the two sites previously mentioned, with no significant differences (Table 2). Discriminant analysis showed that $86.5 \%$ of the total variation was explained by the first axis. The variable best represented along this axis was $\mathrm{Ba}$ :Ca ratio (eigenvalue $=0.73$ ), followed by $\mathrm{Sr}: \mathrm{Ca}$ ratio (eigenvalue $=0.45$ ). Values for Cubagua Island were obtained towards the positive values of the first canonical axis, while La Guardia values were obtained towards the negative ones (Figure 2). An overlap of the values corresponding to both lagoons and Guamache localities was observed (Figure 2). Manzanillo site showed widely dispersed values, overlapping with the ones of Cubagua Island.

\subsection{Elemental water chemistry and Sr:Ca partition coefficients}

The water Sr:Ca ratio ranged between 2.87 and $3.28 \mathrm{mmol} / \mathrm{mol}$, with the highest value corresponding to the localities of La Guardia and Cubagua Island, and the lowest to Manzanillo (Figure 3). The remaining sampling sites presented intermediate values (Figure 3). The analysis of variance for $\mathrm{Sr}$ :Ca partition coefficients showed similar values for Cubagua Island and Manzanillo localities (Figure 4). They were significantly different from Guamache, La Isleta and La Guardia sites that presented the lower partition coefficients (Figure 4). The lagoons Punta de Piedras and La Restinga showed intermediate values (Figure 4).

\section{Discussion}

The incorporation of $\mathrm{Sr}: \mathrm{Ca}$ and $\mathrm{Ba}: \mathrm{Ca}$ in the otolith depends on several factors, particularly, elemental water chemistry, salinity and temperature (Kraus and Secor, 2004; Miller, 2011; Sturrock et al., 2012). Temperature can have a negative, positive or no effect on the incorporation of these elements to the otolith. However, this relationship is dependent on the species and it is necessary to assess it through experimental research like breeding specimens in captivity (Campana, 1999; Brown and Severin, 2009; Sturrock et al., 2012). For mullets these relationships have not yet been studied. In the area selected for this study, temperature (approx. 23.5-24.5 ${ }^{\circ} \mathrm{C}$ ) and salinity (35.8-36.6 UPS) of water do not vary significantly throughout the year (Astor and Cárdenas, 1997).

In this work the higher $\mathrm{Sr}: \mathrm{Ca}$ and $\mathrm{Ba}: \mathrm{Ca}$ (3.64 and $0.024 \mathrm{mmol} / \mathrm{mol}$, respectively) ratios for M. curema otoliths were found in Cubagua Island (Table 2), while the lower ratios correspond to La Guardia locality (2.65 and $0.009 \mathrm{mmol} / \mathrm{mol}$, respectively). The high values

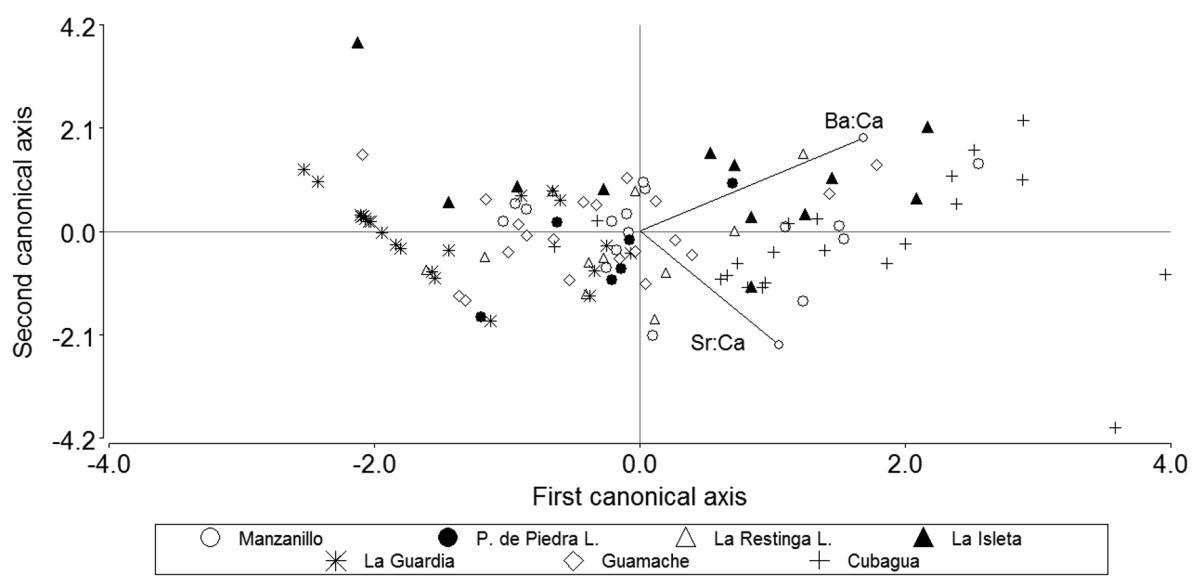

Figure 2. Discriminant analysis for otolith Sr:Ca and Ba:Ca ratios of Mugil curema for the sampling sites in Nueva Esparta State.

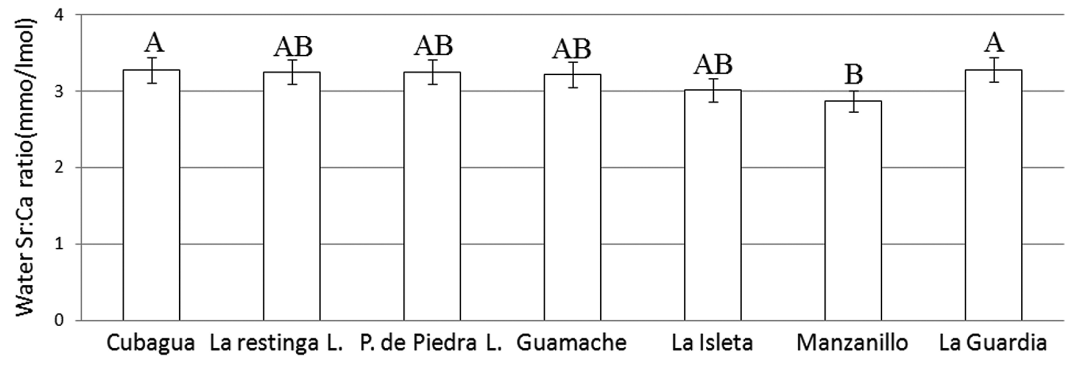

Figure 3. Water Sr:Ca ratios (mmol/mol) for Mugil curema sampling sites in Nueva Esparta State. P. de Piedras (Punta de Piedras), L (Lagoon). Error bars represent standard deviation. Significant differences are shown with different letters $(\mathrm{p}<0.05)$. 


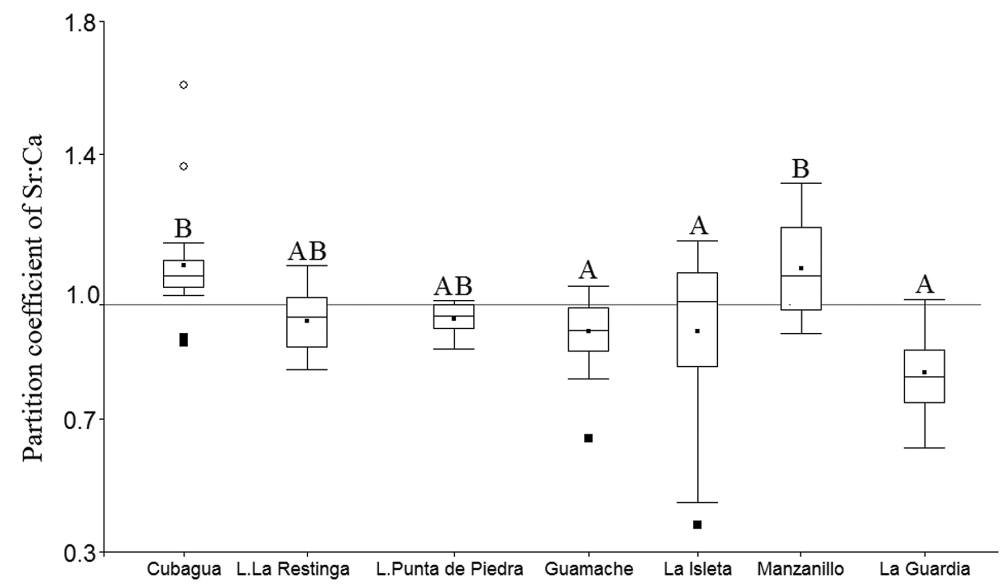

Figure 4. Partition coefficient of Sr:Ca ratios for the sampling sites of Mugil curema in Nueva Esparta State. L (Lagoon). Error bars represent standard deviation. Significant differences are shown with different letters $(\mathrm{p}<0.05)$.

of the otolith $\mathrm{Sr}: \mathrm{Ca}$ ratios coincides with water $\mathrm{Sr}: \mathrm{Ca}$ ratios (Figure 3), as previously reported by other authors (i.e., Kraus and Secor, 2004; Avigliano and Volpedo, 2013). The discriminant analysis among otolith $\mathrm{Sr}: \mathrm{Ca}$ and $\mathrm{Ba}: \mathrm{Ca}$ ratios also showed a separation between Cubagua Island and La Guardia values (Figure 2).

In the analysis of partition coefficients, usually used to describe relationships between elemental concentrations in otolith and in water (e.g. Tabouret et al., 2010; Santos et al., 2013), a coefficient of 1 represents elemental deposition into the otolith in equal proportion as the environment concentrations, while values lower than 1 represent elemental discrimination, and values higher than 1 represent active elemental uptake (Elsdon and Gillanders, 2003, 2005). Except for La Guardia $\left(\mathrm{D}_{\mathrm{Sr}_{\mathrm{r}}}=0.81\right)$, all partition coefficients were close to $1\left(\mathrm{D}_{\mathrm{Sr}}=0.92-1.10\right)$, showing that $\mathrm{Sr}$ :Ca ratios of otoliths were similar as ratios from surrounding water. Lower values of $\mathrm{D}_{\mathrm{sr}}$ were reported by some authors for other marine (0.28) (De Vries et al., 2005) and freshwater species (0.49) (Tabouret et al., 2010), but, the methodology of total otolith digestion used in the present study could be representing a loss in analysis definition, given that it represents an average of the life history of the fish. Additionally, the relatively low partition coefficient of mullets from La Guardia would be partially explained by other factors, such as the migratory behavior of this species. The silver mullet moves from its main spawning area, located near Fosa de Cariaco between La Tortuga and Margarita islands (with a maximum depth above $1500 \mathrm{~m}$ ), to Margarita Island (Etchevers, 1974). Coastal catches of mullets are uncommon during the spawning period in the open sea (April-July and September-October) (Moore, 1974). Approximately 14 days after hatching, larvae metamorphose and are carried by the currents to depths above $50 \mathrm{~m}$, in the estuarine areas, such as mangles and coastal lagoons, where they live until reaching recruitment age (Marin et al., 2003). Less-intense spawnings have also been reported from March to October in Golfo de Cariaco, located in the south of Nueva Esparta State, and from July to September in La Restinga lagoon (Marin et al., 2003). Studies carried out in other regions of the Caribbean Sea (Mexican Gulf), demonstrated that $M$. curema spawns both in freshwater and open-sea waters, and that they spend most of their life in brackish waters, migrating annually to the spawning areas (Ibañez et al., 2012).

Baumar et al. $(2000,2003)$ also reported that M. curema uses salt water-lagoons not only as nurseries but also as hatching areas. These environments distinguish for having high salinity concentrations (36-45 g/L) (Rocha et al., 2010). This concurs with high Sr:Ca ratios found in fish otoliths for both lagoons studied. On this basis, the differences found in the otolith microchemistry between fish from the La Restinga and Punta de Piedras Lagoons and south regions of Margarita Island (e.g. Cubagua Island) may be explained by the permanence of fish populations in these different spawning areas.

Significant differences were found in otolith $\mathrm{Sr}: \mathrm{Ca}$ and $\mathrm{Ba}$ :Ca ratios among study areas; particularly between the localities of La Guardia, in the north of the State, and Cubagua Island in the south. This could be showing the possible existence of different groups of mullets in southeastern Caribbean Sea, suggesting that simultaneous use of $\mathrm{Sr}: \mathrm{Ca}$ and $\mathrm{Ba}: \mathrm{Ca}$ ratios could be a potential identifier of populations in the study area. However, this identification was not clear enough. This could be due to diverse reasons, but mostly the microchemical analysis of the whole otolith (a methodology reachable in South America and with relatively low-cost) can result in errors or limitations of interpretation because it doesn't take into account the life history of the fish, especially for those species with long distance movements. Further research is needed to confirm and gain a more in-depth insight of the interaction between these fish stocks, with the use of additional methodologies like microchemical analysis of the otolith by age (using the $\mathrm{Sr}: \mathrm{Ca}$ and $\mathrm{Ba}: \mathrm{Ca}$ ratios as an indicator of habitat), parasitological studies, etc. 


\section{Acknowledgements}

We are grateful to the Universidad de Buenos Aires (UBACYT 20620110100007), ANPCyT (PICT 2010-1372) and CONICET (PIP 112-20120100543CO) for financial support. We would like to thank the Estación de Investigaciones Marinas de Margarita, Fundación La Salle de Ciencias Naturales de Venezuela, and M. Rada, J. M. Guaiquirian and C. Salazar. We are also grateful to the reviewers for their insight and their helpful and constructive comments for improving the manuscript.

\section{References}

AMERICAN PUBLIC HEALTH ASSOCIATION - APHA, 1993. Métodos normalizados para el análisis de aguas potables $y$ residuales. 17th ed. Washington: APHA.

ASTOR, Y. and CÁRDENAS, J., 1997. Informe de la sexta campaña del proyecto de evaluación pesquera VECEP (Venezuela, Colombia, Ecuador y Perú). Caracas: Programa de Cooperación Técnica para la Pesca UE-VECEP ALA 92/43, UE-VECEP. 72 p. Informe para la Unión Europea.

AVIGLIANO, E. and VOLPEDO, A.V., 2013. Use of otolith strontium:calcium ratio as indicator of seasonal displacements of the silverside (Odontesthes bonariensis) in a freshwater-marine environment. Marine \& Freshwater Research, vol. 64, no. 8, pp. 746-751. http://dx.doi.org/10.1071/MF12165.

AVIGLIANO, E., RIAÑOS MARTINEZ, C. and VOLPEDO, A.V., 2013. Combined use of otolith microchemistry and morphometry as indicators of the habitat of the silverside (Odontesthes bonariensis) in a freshwater-estuarine environment. Fish Resesearch, vol. 149, pp. 55-60. http://dx.doi.org/10.1016/j.fishres.2013.09.013.

BAUMAR, J., MARIN, E. and DODSON, J., 2000. Age, growth and fecundity of the silver mullet, Mugil curema (Pisces: Mugilidae), in coastal areas of Northeastern Venezuela. Revista de Biologia Tropical, vol. 48, no. 2-3, pp. 389-398. PMid:11354946.

BAUMAR, J., MARIN, E. and QUINTERO, E., 2003. Reproduction and recruitment of white mullet (Mugil curema) to a tropical lagoon (Margarita Island, Venezuela) as revealed by otolith microstructure. Fish Bulletin, vol. 101, no. 4, pp. 809-821.

BEGG, G., OVERHOLTZ, W. and MUNROE, N., 2001. The use of internal otolith morphometrics for identification of haddock (Melanogrammus aeglefinus) stocks on Georges Bank. Fish Bulletin, vol. 99, pp. 1-14.

BROWN, R.J. and SEVERIN, K.P., 2009. Otolith chemistry analyses indicate that water $\mathrm{Sr}: \mathrm{Ca}$ is the primary factor influencing otolith $\mathrm{Sr}: \mathrm{Ca}$ for freshwater and diadromous fish but not for marine fish. Canadian Journal of Fisheries and Aquatic Sciences, vol. 66, no. 10, pp. 1790-1808. http://dx.doi.org/10.1139/F09-112.

BURKE, N., BROPHY, D. and KING, P., 2008. Otolith shape analysis: its application for discriminating between stocks of Irish Sea and Celtic Sea herring (Clupea harengus) in the Irish Sea. ICES Journal of Marine Science, vol. 65, no. 9, pp. 1670-1675. http://dx.doi.org/10.1093/icesjms/fsn177.

CAMPANA, S., 1999. Chemistry and composition of fish otoliths: pathways, mechanisms and applications. Marine Ecology Progress Series, vol. 188, pp. 263-297. http://dx.doi.org/10.3354/meps188263.
CARDINALE, M., DOERING-ARJES, P., KASTOWSKY, M. and MOSEGAARD, H., 2004. Effects of sex, stock, and environment on the shape of known-age Atlantic cod (Gadus morhua) otoliths. Canadian Journal of Fisheries and Aquatic Sciences, vol. 61, no. 2, pp. 158-167. http://dx.doi.org/10.1139/f03-151.

CHIBA, W.A.C., PASSERINI, M.D. and TUNDISI, J.G., 2011. Metal contamination in benthic macroinvertebrates in a sub-basin in the southeast of Brazil. Brazilian Journal of Biology $=$ Revista Brasileira de Biologia, vol. 71, no. 2, pp. 391-399. http://dx.doi. org/10.1590/S1519-69842011000300008. PMid:21755156.

DE VRIES, M.C., GILLANDERS, B.M. and ELSDON, T.S., 2005. Facilitation of barium uptake into fish otoliths: influence of strontium concentration and salinity. Geochimica et Osmochimica Acta, vol. 69, no. 16, pp. 4061-4072. http://dx.doi.org/10.1016/j. gca.2005.03.052.

ELSDON, T. and GILLANDERS, B., 2003. Relationship between water and otolith elemental concentrations in juvenile black bream Acanthopagrus butcheri. Marine Ecology Progress Series, vol. 260, pp. 263-272. http://dx.doi.org/10.3354/meps260263.

ELSDON, T. and GILLANDERS, B., 2005. Alternative life-history patterns of estuarine fish: barium in otoliths elucidates freshwater residency. Canadian Journal of Fisheries and Aquatic Sciences, vol. 62, no. 5, pp. 1143-1152. http://dx.doi.org/10.1139/f05-029.

ETCHEVERS, S., 1974. Fecundidad de la lisa (Mugil curema Valenciennes) en el Oriente de Venezuela. Cumaná: Universidad de Oriente, Centro de Investigaciones de Cumaná, pp. 1-19. Boletín Científico Técnico Recursos Marinos CIC UDO, no. 1.

FERGUSON, G., WARDA, T. and GILLANDERS, B., 2011. Otolith shape and elemental composition: Complementary tools for stock discrimination of mulloway (Argyrosomus japonicus) in southern Australia. Fisheries Research, vol. 110, no. 1, pp. 17-83. http://dx.doi.org/10.1016/j.fishres.2011.03.014.

FOOD AND AGRICULTURE ORGANIZATION OF THE UNITED NATIONS - FAO, 2005 [viewed 3 October 2013]. Fishery country profile: la República Bolivariana de Venezuela [online]. Rome: FAO. Available from: www.fao.org

FOOD AND AGRICULTURE ORGANIZATION OF THE UNITED NATIONS - FAO, 2010. Marco nacional de prioridades a mediano plazo en la República Bolivariana de Venezuela: Anexo 2: análisis situacional: seguridad alimentaria, sector agropecuario, forestal, pesca y recursos naturales. Rome: FAO. $18 \mathrm{p}$.

GALLEY, E., WRIGHT, P. and GIBB, F., 2006. Combined methods of otolith shape analysis improve identification of spawning areas of Atlantic cod. ICES Journal of Marine Science, vol. 63, no. 9, pp. 1710-1717. http://dx.doi.org/10.1016/j.icesjms.2006.06.014.

GONZÁlEZ CASTRO, M., HERAS, S., COUSSEAU, M.B. and ROLDÁN, M.I., 2008. Assessing species validity of Mugil platanus Günther, 1880 in relation to Mugil cephalus Linnaeus, 1758 (Actinopterygii). The Italian Journal of Zoology, vol. 75, no. 3, pp. 319-325. http://dx.doi.org/10.1080/11250000801886254.

HAMER, P., JENKINS, G. and COUTIN, P., 2006. Barium variation in Pagrus auratus (Sparidae) otoliths: a potential indicator of migration between an embayment and ocean waters in southeastern Australia. Estuarine, Coastal and Shelf Science, vol. 68, no. 3-4, pp. 686-702. http://dx.doi.org/10.1016/j.ecss.2006.03.017.

HARRISON, I., 2002. Mugilidae. In: K. KARPENTER, ed. FAO Species identification guide for fisheries purposes: the living marine resources of the western Central Atlantic. Rome: 
FAO, pp. 1071-1085. Bony Fishes, part 1 (Acipenseridae to Grammatidae), vol. 2.

HARRISON, I., NIRCHIO, M., OLIVEIRA, C., RON, E. and GAVIRIA, J., 2007. A new species of mullet (Teleostei: Mugilidae) from Venezuela, with a discussion on the taxonomy of Mugil gaimardianus. Journal of Fish Biology, vol. 71, no. sa, pp. 76-97. http://dx.doi.org/10.1111/j.1095-8649.2007.01520.x.

HERAS, S., ROLDÁN, M. and GONZÁLEZ-CASTRO, M., 2009. Molecular phylogeny of Mugilidae fishes revised. Reviews in Fish Biology and Fisheries, vol. 19, no. 2, pp. 217-231. http:// dx.doi.org/10.1007/s11160-008-9100-3.

IBÁÑEZ, A.L., CHANG, C.W., HSU, C.C., WANG, C.H., IIZUKA, Y. and TZENG, W.N., 2012. Diversity of migratory environmental history of the mullets Mugil cephalus and M. curema in Mexican coastal waters as indicated by otolith $\mathrm{Sr}: \mathrm{Ca}$ ratios. Ciencias Marinas, vol. 38, no. 1A, pp. 73-87. http://dx.doi.org/10.7773/ cm.v38i1A.1905.

KRAUS, R. and SECOR, E., 2004. Incorporation of strontium into otoliths of an estuarine fish. Journal of Experimental Marine Biology and Ecology, vol. 302, no. 1, pp. 85-106. http://dx.doi. org/10.1016/j.jembe.2003.10.004.

LIN, S., CHANG, S., IIZUKA, Y. and TZENG, W., 2007. Salinities, not diets, affect strontium/calcium ratios in otoliths of Anguilla japonica. Journal of Experimental Marine Biology and Ecology, vol. 341, no. 2, pp. 254-263. http://dx.doi.org/10.1016/j. jembe.2006.10.025.

MARIN, E., QUINTERO, A., BUSSIERE, D. and DODSON, J., 2003. Reproduction and recruitment of white mullet (Mugil curema) to a tropical lagoon (Margarita Island, Venezuela) as revealed by otolith microstructure. Fish Bulletin, vol. 101, pp. 809-821.

MCCULLOCH, M., FALLON, S., WYNDHAM, T., HENDY, E., LOUGH, J. and BARNES, D., 2003. Coral record of increased sediment flux to the inner Great Barrier Reef since European settlement. Nature, vol. 421, no. 6924, pp. 727-730. http://dx.doi. org/10.1038/nature01361. PMid:12610621.

MENDES, G.N., 1983. Estudo sobre aclimatação de alevinos de tainha (Mugil curema Valenciennes, 1836) à agua doce. Brazilian Journal of Biology $=$ Revista Brasileira de Biologia, vol. 2, no. 1, pp. 13-33.

MENDONÇA, J.T. and BONFANTE, T.M., 2011. Assessment and management of white mullet Mugil curema (Valencienne, 1836) (Mugilidae) fisheries of the south coast of São Paulo state. Brazilian Journal of Biology = Revista Brasileira de Biologia, vol. 71, no. 3, pp. 663-672. PMid:21881789.

MILLER, J., 2011. Effects of water temperature and barium concentration on otolith composition along a salinity gradient: Implications for migratory reconstructions. Journal of Experimental Marine Biology and Ecology, vol. 40, no. 1-2, pp. 42-52. http:// dx.doi.org/10.1016/j.jembe.2011.05.017.

MOORE, R., 1974. General ecology, distribution and relative abundance of Mugil cephalus and Mugil curema on the south Texas coast. Contributions in Marine Science, vol. 18, pp. 241-255.

MULLER-KARGER, F., MCCLAIN, C., FISHER, T., ESAIAS, W. and VARELA, R., 1989. Pigment distribution in the Caribbean
Sea: observations from space. Progress in Oceanography, vol. 23, no. 1, pp. 23-64. http://dx.doi.org/10.1016/0079-6611(89)90024-4.

NELSON, J.S., 2006. Fishes of the world. 4th ed. Hoboken: John Wiley \& Sons. 601 p.

RIVERA-REYES, J., 2009. Análisis morfométrico discriminante de cinco especies de peces del género Mugil (Teleostei: Mugilidae). Boca de Río: Escuela de Ciencias Aplicadas del Mar, Universidad de Oriente, 61 p. PhD Thesis.

ROCHA, R., GUERRA-CASTRO, E., LIRA, C., PAULS, S., HERNÁNDEZ, I., PÉREZ, A., SARDI, A., PÉREZ, J., HERRERA, C., CARBONINI, A., CARABALLO, V., SALAZAR, D., DIAZ, M. and CRUZ-MOTTA, J., 2010. Inventory of ascidians (Tunicata, Ascidiacea) from the National Park La Restinga, Isla Margarita, Venezuela. Biota Neotropica, vol. 10, no. 1, pp. 209-218. http:// dx.doi.org/10.1590/S1676-06032010000100021.

SANTOS, P.R., TANNER, E.S., ELSDON, T.S., CABRAL, H.N. and GILLANDERS, B.M., 2013. Effects of temperature, salinity and water composition on otolith elemental incorporation of Dicentrarchus labrax. Journal of Experimental Marine Biology and Ecology, vol. 446, pp. 245-252. http://dx.doi.org/10.1016/j. jembe.2013.05.027.

SCHUCHERT, P., ARKHIPKIN, A. and KOENIG, A., 2010. Traveling around Cape Horn: otolith chemistry reveals a mixed stock of Patagonian hoki with separate Atlantic and Pacific spawning grounds. Fisheries Research, vol. 102, no. 1-2, pp. 80-86. http://dx.doi.org/10.1016/j.fishres.2009.10.012.

SOKAL, R. and ROHLF, F., 1995. Biometry: the principles and practice of statistics in biological research. 3rd ed. New York: W. H. Freeman. 887 p.

STURROCK, A.M., TRUEMAN, C.N., DARNAUDE, A.M. and HUNTER, E., 2012. Can otolith elemental chemistry retrospectively track migrations in fully marine fishes. Journal of Fish Biology, vol. 81 , no. 2 , pp. 766-795. http://dx.doi.org/10.1111/j.10958649.2012.03372.x. PMid:22803735.

TABOURET, H., BAREILLE, G., CLAVERIE, F., PÉCHEYRAN, C., PROUZET, P. and DONARD, O.F.X., 2010. Simultaneous use of strontium:calcium and barium:calcium ratios in otoliths as markers of habitat: application to the European eel (Anguilla anguilla) in Adour Basin, South West France. Marine Environmental Research, vol. 70, no. 1, pp. 35-45. http://dx.doi.org/10.1016/j. marenvres.2010.02.006. PMid:20338633.

UNITED STATES ENVIRONMENTAL PROTECTION AGENCY - EPA, 1994. Methods for the determination of metals in environmental samples. Ohio: EPA. 58 p. Supplement 1.

WELLS, B., RIEMAN, B., CLAYTON, J., HORAN, D. and JONES, C., 2003. Relationships between water, otoliths, and scale chemistries of Westslope cutthroat trout from the Coeur d'Alene River, Idaho: the potential application of hard-part chemistry to describe movements in freshwater. Transactions of the American Fisheries Society, vol. 132, no. 3, pp. 409-424. http://dx.doi. org/10.1577/1548-8659(2003)132<0409:RBWOAS >2.0.CO;2.

ZLOKOVITZ, E., SECOR, D. and PICCOLI, P., 2003. Patterns of migration in Hudson River striped bass as determined by otolith microchemistry. Fisheries Research, vol. 63, no. 2, pp. 245-259. http://dx.doi.org/10.1016/S0165-7836(03)00069-9. 